"This is an Author's Accepted Manuscript of an article published in African Historical Review, Vol. 44, No. 1 (2012) p. 80-108, Version of record first published: 22 Nov 2012

Taylor \& Francis $(\mathcal{C}$, available online at:

http://www.tandfonline.com/doi/abs/10.1080/17532523.2012.714161 (Access to the

published version may require subscription)"

\title{
“They Treat Us Like Dogs”: Demographic Claustrophobia and the Zimbabwean Struggle for Space on the Streets of Gaborone, Botswana ${ }^{12}$
}

\author{
Stephen Marr \\ Department of Global Political Studies, Malmö University \\ Department of Political Science, Linnaeus University
}

\section{Introduction}

On 9 November 1965 Q. K. J. Masire - the eventual second president of Botswana - penned a memo for the Ministry of Home Affairs describing an outburst of violence that culminated in a near riot between Batswana and the Rhodesian labourers hired to construct Botswana's new capital city. ${ }^{3}$ The dispute began mundanely enough. The initial spark came when a Motswana man emptied the contents of a water bucket carried by a foreign female laborer employed by the Costains construction company. Later that evening, her Rhodesian husband returned to Naledi, the squatter settlement where the standpipe was located, in order to protest her treatment. Shortly after arriving the confrontation escalated as he was thrown into a hut that was then (allegedly) set on fire. Though managing to escape the encounter unscathed, the next night the

\footnotetext{
${ }^{1}$ Steve Marr is a Visiting Senior Lecturer in Political Science (Linnaeus University, Sweden) and Global Political Studies (Malmö University, Sweden). The fieldwork on which this article is based was made possible through a Fulbright Dissertation Grant. The author thanks both his colleagues in Sweden and former colleagues at Haverford College and the University of Florida for their input and encouragement, Paul Landau for the invitation to participate in this special issue, and all the people in Gaborone's White City who were gracious hosts in difficult times. This essay is adapted from the author's dissertation, 'Spaces of Aspiration, Liberation and Exclusion: The Politics of Urban Space in an African Democracy' (PhD thesis, University of Florida, 2008). See especially the latter half of Chapter 5, "Down on the Corner: Illegal Immigration and the Struggle for Space on the Streets of Gaborone, Botswana".

${ }^{2}$ This article appeared in a special issue of African Historical Review, Vol. 44, No. 1 (2012) on "Witcheraft and Xenophobic Violence in Modern South Africa."

${ }^{3}$ Botswana National Archives (hereafter BNA), Ministry of Local Government and Land Audit Department (hereafter MLGL) 1 Box 27, Squatters: Gaborone Town Council 10 Aug. 1966 - 2 May 1968, Q. K. J. Masire memo on Security - Disturbances Gaberones Township, 9 Nov. 1965.
} 
same man was severely beaten upon returning with some friends to settle the score. Masire narrates what happened next:

Thereafter the situation deteriorated and it appeared there might be serious trouble. After 9pm forces of about 350 Batswana and 300 Rhodesians were preparing for a free for all when the police arrived and prevented further trouble. It was necessary for the police to disarm members of both factions of weapons such as sticks, clubs, and bicycle chains. The situation was quiet by $1 \mathrm{am}$. Full police patrols were carried on (sic) throughout the night, and the police have been patrolling and watching the situation carefully since. ${ }^{4}$

Although a large-scale conflagration was averted in this particular instance, an Italian contractor who oversaw the painting of newly constructed housing in Gaborone remembered both government officials and employers as being "very scared" about the possibility of further conflicts between the two sides because the "locals didn't want the foreigners" taking jobs they thought should be theirs. ${ }^{5}$ Masire came to a similar conclusion. He noted that "though the immediate cause of the dispute was the water incident, it is believed that the ill-feeling of the Batswana against the Rhodesians stems from deep jealously of the Rhodesians' generally better pay, housing and labour conditions."

While this episode occurred over forty-five years ago, before Bechuanaland became Botswana, it anticipates the tensions and arguments repeated today on the streets, and in the newspapers, shops and bars of contemporary Gaborone. Indeed, the public debate over issues of belonging, citizenship and access to employment opportunities - exemplified in the above example continue to be one of the primary sources of political and social tension in Botswana. ${ }^{7}$ And although the narrative of the country's political and economic virtues has long been commonplace amongst academics, the media and policymakers ${ }^{8}$ there is an emerging sense that

\footnotetext{
${ }^{4}$ Ibid.

${ }^{5}$ Interview, Alberto Travaglini, Gaborone, 19 Feb. 2005.

${ }^{6}$ BNA, MLGL 1 Box 27, Security - Disturbances Gaberones Township, 9 Nov. 1965.

${ }^{7}$ R. Werbner, Reasonable Radicals and Citizenship in Botswana: The Public Anthropology of Kalanga Elites (Bloomington: Indiana University Press, 2004); R. Werbner (ed), 'Minorities and Citizenship in Botswana', Journal of Southern African Studies (Special Issue), 28, 4 (2002).

${ }^{8}$ A sampling of this literature includes: L. A. Picard (ed), The Evolution of Modern Botswana (Lincoln: University of Nebraska Press, 1985); S. J. Stedman (ed), Botswana: The Political Economy of Democratic Development (Boulder: Lynne Rienner Publishers, 1993); D. Acemoglu, S. Johnson, and J. A. Robinson, 'An African Success Story: Botswana' (CEPR Discussion Papers 3219, Centre for Economic Policy Research, London, 2002); A. I. Samatar, An African Miracle: State and Class Leadership and Colonial Legacies in Botswana Development
} 
Africa's Exception is becoming increasingly less so. ${ }^{9}$ These sentiments are expressed outside academic circles as well. Consider, for example, a 2006 newspaper editorial authored by Dumelang Saleshando, an MP from the opposition Botswana Congress Party (BCP). In this piece Saleshando suggests that the make-up of the national economy is little changed from independence. Capturing the feelings of powerlessness and economic isolation held by many Batswana citizens, he writes,

Forty years after independence, the structure of our economy has not changed much. The indigenous Batswana, previously referred to as natives, provide a pool of labour to the white entrepreneurs who own the means of production....The citizens have become spectators...[and] their hope to corporate success does not transcend an ailing small general dealer, bar and bottle store, or more miserably, a roadside mobile phone service. ${ }^{10}$

Saleshando concludes, "What is the worth of our independence, when the wealth of our country eludes a majority of us?" 11 Some observers have noted that the policies of development pursued by the ruling Botswana Democratic Party since $1966^{12}$ have excluded most Batswana from the national economy at worst, or permitted them only supporting or bit parts at best. In the popular conscious however, as Saleshando's text indicates, blame for the citizenry's economic marginalization is placed at the feet of immigrants. Perhaps literally so for the Zimbabweans who daily stand on the streets of White City in search of employment.

The remaining text therefore sketches the day to day contours of these interactions. I emphasize the conversations, encounters, and stories of first, Batswana, and later, those of Zimbabwean immigrants who have made their way to Gaborone. The goals of the text are both theoretical and

(Portsmouth: Heinemann, 1999); J. C. Leith, 'Why Botswana prospered' (Canadian Economics Association ThirtyFourth Annual Meetings, University of British Columbia, June 2000).

${ }^{9}$ Regarding Botswana's increased military spending, see: D. Henk, 'The Botswana Defence Force: Evolution of a Professional African Military', African Security Review, 13, 4 (2004). For a discussion of free speech in the context of academic freedom, see: S. Pegg, 'Presidential Succession and Academic Freedom: Botswana Deports Leading Political Scientist Kenneth Good', PS Online, (October 2005), 829; I. Taylor, 'The Limits of the 'African Miracle': Academic Freedom in Botswana and the Deportation of Kenneth Good', Journal of Contemporary African Studies, 24, 1 (January 2006). Finally, for a critical discussion of Botswana's democratic and economic policies, see: K. Good, 'At the Ends of the Ladder: Radical Inequalities in Botswana', The Journal of Modern African Studies, 31, 2 (June 1993); K. Good, 'The State and Extreme Poverty: the San and Destitutes', The Journal of Modern African Studies, 37, 2 (June 1999).

${ }^{10}$ D. Saleshando, 'What is the Worth of Our Independence?', Mmegi, 8 May 2006 $<$ http://www.mmegi.bw/2006/May/Monday8/274371337117.html> (8 May 2006).

${ }^{11}$ Ibid.

${ }^{12}$ Z. Maundeni, 'The Politics of Poverty in Botswana', Botswana Notes and Records, 23 (2003), 107. 
tactile. On the one hand, I intend to give some tangible sense of the politics of everyday life from the perspective of immigrants and the Batswana citizens and authorities with whom the share the streets. That is, I am less concerned in this paper with accounting for the means by which citizen/stranger tensions in Botswana are produced or where they might be located in a wider narrative of macro-processes (e.g. globalization, neo-liberal capitalism's diffusion) than with how they are daily lived and experienced by the city's residents. By aggregating the fragmentary ${ }^{13}$ - gossip, sights, sounds, insults, blusterings, stereotypes - I hope to craft a (snapshot) narrative of everyday life on the streets of Gaborone that complements the increasingly large theoretical literature on autochthony ${ }^{14}$, migration and heterogeneity ${ }^{15}$, and xenophobia $^{16}$ in Botswana ${ }^{17}$ (and elsewhere). At the same time, I would like to situate these stories in a wider frame by offering some preliminary speculations as to how we might understand these street-level conflicts and encounters in biopolitical terms. What I mean by this is to say that I am interested in examining to how the State's biopolitical goals are implemented the level of the everyday. I intend to use observations and stories to gain insight into the extent to which it is possible to speak of a "leaky" biopolitics.

\footnotetext{
${ }^{13}$ Martin Murray deploys the term “'empirically grounded vignettes"” in his piece on anti-immigrant violence in South Africa. See: M. J. Murray, 'Alien Strangers in Our Midst: The Dreaded Foreign Invasion and 'Fortress South Africa", Canadian Journal of African Studies, 37, 2/3 (2003), 442.

${ }^{14}$ A sampling of this diverse literature includes: P. Geschiere and F. Nyamnjoh, 'Capitalism and Autochthony: The Seesaw of Mobility and Belonging', Public Culture, 12, 2 (2000); P. Geschiere and S. Jackson (eds), 'Autochthony and the Crisis of Citizenship', African Studies Review (Special Issue), 49, 2 (2006); P. Geschiere, The Perils of Belonging: Autochthony, Citizenship, and Exclusion in Africa and Europe (Chicago: University of Chicago Press, 2009); J. Comaroff and J. Comaroff, 'Naturing the Nation: Aliens, Apocalypse and the Postcolonial State', Journal of Southern African Studies, 27, 3 (2001). For a more wide-ranging theoretical discussion of the structural forces at work in the politics of autochthony, see: M. Foucault, Society Must Be Defended (London: Allen Lane, 2003); G. Agamben, Homo Sacer: Sovereign Power and Bare Life (Stanford: Stanford University Press, 1998); Z. Bauman, Wasted Lives: Modernity and its Outcasts (Cambridge: Polity Press, 2004).

${ }^{15} \mathrm{~J}$. Comaroff and J. Comaroff, 'Reflections on Liberalism, Policulturism, and ID-ology: Citizenship and Difference in South Africa', Social Identities, 9, 4 (2003); L. B. Landau and T. Monson, 'Displacement, Estrangement and Sovereignty: Reconfiguring State Power in Urban South Africa', Government and Opposition, 43, 2 (2008); L. B. Landau, 'Loving the Alien? Citizenship, Law and the Future in South Africa's Demonic Society', African Affairs, 109, 435 (2010); B. Maharaj, 'Migrants and Urban Rights: Politics of Xenophobia in South African Cities', L'Espace Politique, 8, 2 (2009).

${ }^{16}$ B. Dodson, 'Locating Xenophobia: Debate, Discourse and Everyday Experience in Cape Town, South Africa', Africa Today, 56, 3 (2010); M. Neocosmos, 'The Politics of Fear and the Fear of Politics: Reflections on Xenophobic Violence in South Africa', Journal of Asian and African Studies, 43, 6 (2008).

${ }^{17}$ W. Morapedi, 'Post-Liberation Xenophobia in Southern Africa: The Case of the Influx of Undocumented Zimbabwean Immigrants in Botswana, c. 1995-2004', Journal of Contemporary African Studies, 25, 2 (2007); E. K. Campbell, 'Attitudes of Batswana Citizens Towards Immigrants: Signs of Xenophobia?', International Migration, 41, 4 (2003); F. B. Nyamnjoh, Insiders and Outsiders: Citizenship and Xenophobia in Contemporary Southern Africa (Dakar: CODESRIA, 2006).
} 
Before continuing, here are some preliminary remarks to frame the discussion. One of the primary purposes of biopolitics is to categorize populations within a given territory in order to better manage, regulate or govern the body politic. ${ }^{18}$ In pursuit of the most easily administered population, groups are often compartmentalized into two starkly delineated groups, such as normal/abnormal, mainstream/deviant, citizen/stranger. For insight into how these categorizations might function in practice, or what their limitations might be, recent work on autochthony is instructive. The task of autochthonous discourses is to determine who belongs in a given area versus those who might not. And while these discourses of belonging give the appearance of durability and solidity, they in fact remain brittle, ambiguous and in need of constant revision or rhetorical juggling. Peter Geschiere, for example, speaks of these discourses" "tortuous struggles to come to terms with history, which always undermines the apparent self-evidence of chthonic belonging...."19 Along similar lines, it has been suggested elsewhere that the narrative's "very emptiness, the elusiveness of who is 'really' an autochthon gives it a dizzy quality." 20 Despite these difficulties they are popularly deployed globally as part of the struggle over the allocation of state resources or who is a legitimate member of a particular community.

At the same time, deployed under the auspices of biopolitics, these labels and categorizations carry a weight that has significant implications for governing a population. Referring to immigrants in South Africa, Martin Murray observes, "[n]ames are an integral part of both a symbolic and material order that confers legitimacy on those with the power to affix labels to others, and, conversely, de-legitimates those burdened with bearing the stigma of 'otherness.",21 The deployment of these labels identifying "others" is crucial to the task of "specifying any and every form of life that can be held to instill degenerative effects within the field of population.",22 Biopolitics, then, is dependent on the actualization of metaphors that conceive of the state-as-

\footnotetext{
${ }^{18}$ W. Schinkel, 'From Zoepolitics to Biopolitics: Citizenship and the Construction of 'Society', European Journal of Social Theory, 13, 2 (2010), 158.

${ }_{19}$ Geschiere, The Perils of Belonging, 13.

${ }^{20}$ B. Cueppens and P. Geschiere, 'Autochthony: Local or Global? New Modes in the Struggle Over Citizenship and Belonging in Africa and Europe', Annual Review of Anthropology (2005), 396.

${ }^{21}$ Murray, 'Alien Strangers in our Midst', p. 447.

22 J. Reid, 'Life Struggles: War, Discipline, and Biopolitics in the Thought of Michel Foucault', Social Text, 24, 1 (2006), 148.
} 
container so as to protect the integrity and purity of the population inside its borders. ${ }^{23}$ As we will see in the case ahead, the problem goes beyond the popular perception that the behavior(s) of Zimbabweans in Gaborone produces increased levels of criminality or immorality, but rather, it is that the sheer fact of their being visible on White City's streets represents a risk to the population. ${ }^{24}$ More than an accumulation of macro-knowledge about population trends or statistics, biopolitical practice in White City becomes a literal policing of the social body and the spaces it inhabits with the goal of excising malignancies that do not belong. These objectives require the cooperation of citizens and/or authorities or occupy the everyday spaces that need to be policed. The trouble for the successful implementation of biopolitics, however, is that there is a gap between what actually happens and what is supposed to happen. This dissonance occurs because of the ambiguity of identity - the categorization of populations - as it is everyday performed, along with the uneven, perhaps even theatrical, deployment of police power.

With the above as preface, the remainder of the essay is divided into two larger components. In the next section, I give an account of the perception of foreigners from the Batswana perspective with two objectives in mind. First, I show that Zimbabweans as a group are not the only source of ire in contemporary Botswana. And second, I demonstrate that these tensions are not new by historicizing interactions with foreign labor. The following section switches vantage points by examining the Zimbabwean presence on the streets of the central Gaborone neighbourhood, White City. Their story offers a significant contrast to the preceding one, while also serving as a supplement to much of the existing literature on Zimbabwean migrants in southern Africa. Here, we glimpse a more nuanced portrait of the routines, aspirations, and challenges of daily life, rather than simply rehashing grim tales of marginalization or violence. The concluding section draws connections between the ethnographic components and the introductory theoretical discussion.

\section{Al Qaeda, Zimbabweans and the Founding of Gaborone: Immigrant Tales Past and Present}

\footnotetext{
${ }^{23}$ D. Bigo, 'Security and Immigration: Toward a Critique of the Governmentality of Unease', Alternatives, 27 (2002), 67.

${ }^{24}$ For an elaboration of how this might work in a different context, please see: I. C. Marinaro, 'Between Surveillance and Exile: Biopolitics and the Roma in Italy’, Bulletin of Italian Politics, 1, 2 (2009), 276.
} 
Of interest in this section is how street-level discourse amongst Batswana describes a nation under threat. To this end, most of the popular ire appearing in the print media ${ }^{25}$ and heard in conversations occurring in bars and taxis is directed towards the increasingly visible presence of foreigners. Non-citizen populations are blamed for taking jobs and resources, committing crimes, and causing a general erosion of Tswana morals and culture. At a more basic level, foreigners are said to pose an immediate danger to the viability of Botswana's social and economic future. One street vendor in Gaborone's Main Mall, for example, referred to his Kenyan competition as the "Nigerians of Botswana" who are "cheaters with a forked tongue....[and who] are trying to take Botswana away from us." Similarly, another Motswana in the Main Mall confidently claimed that "Islams" were taking over all the businesses in Gaborone, emphasizing his grievance with the corollary point that "Al Qaeda are everywhere [in Gaborone]."

Some six months later, while sitting in the office of a retired civil servant formerly employed in Gaborone's municipal bureaucracy, I heard the same points elaborated. On the one hand, he aired the suspicion that the increased presence of shops selling Hallal goods reflected a conscious strategy on the part of Muslims to takeover local businesses, since all store owners would have to follow Muslim practice in order to survive. At the same time, the informant expressed a more generalized apprehension about the long-term viability of Batswana-owned businesses in light of the influential presence of Muslim expatriates in the private and public sector. He warned, "If government isn't careful there will be conflict between the Muslims and Black Christians....You can't leave the 98\% [Botswana's non-Muslim population] out of business. Otherwise there will be a war here. Like in Uganda where they kicked out all the Muslims." A well-connected businesswoman put the issue of Muslim ownership of businesses more starkly: "it could turn ugly one day....What nation doesn't rise?" Finishing the thought, she argued that people need protection from external ownership pressures, rhetorically asking, "If the playing field isn't level, how can I compete?"

\footnotetext{
${ }^{25}$ For an in-depth discussion of newspaper accounts of the presence of foreigners in Botswana, see: F. B. Nyamnjoh, 'Local Attitudes towards Citizenship and Foreigners in Botswana: An Appraisal of Recent Press Stories', Journal of Southern African Studies, 28, 4 (2002); S. Marr, "If You are With Ten, Only Two Will be Batswana": NationMaking and the Public Discourse of Paranoia in Botswana', Canadian Journal of African Studies (forthcoming in 2012).
} 
Anxiety over the economy is a common condition for both the well-off and the working poor in Botswana. And criticism is becoming more pointed. One Motswana man I spoke with in the city center, suggests that the government is intentionally putting the poor at a perpetual disadvantage, telling me, "The government wants to make us like Zimbabweans. Cheap labor for these companies. How can you work for two Pula a day? You can't. I would rather die than work for nothing." This statement echoes Saleshando's earlier critique about the failures of development in spite of Botswana's impressive economic growth since 1966's independence. The pervasive feeling of economic insecurity creates the need for scapegoats - Kenyans, Muslims, and later, as we will see, Zimbabweans - who can be held accountable for both the government and the economy's inability to create or maintain a more equitable distribution of resources.

But as I noted at the onset, the perception held by many regarding the ceaseless arrival of outsiders to the detriment of the economic, social or moral well-being of the population has a fairly long historical antecedent, taking shape especially around the time of Gaborone's construction. While I do not want to dwell for too long on the making of Gaborone in the mid1960 s, there are a few points worth making pertinent to the current discussion. ${ }^{26}$ First, from the perspective of government officials and the technical staff charged with developing the blueprints for the city, Gaborone, as a planned capital, was envisioned largely as an administrative center. Consequently, a great deal of energy and attention was spent devising ways - rarely successful when implemented - in which order and legibility could be designed into the spatial environment of the city. In practice, this often meant that planners variously tried to apply strict zoning standards in which low-cost and high-cost housing were kept separate; regulate migration into the city; and prevent the development of slum areas. Protecting Gaborone from the degenerative effects of unauthorized development was a concern from the onset. Authors of one early planning manual, for example, argued that failure to take the "vitally necessary" action to control development both inside and outside the borders of Gaborone would result in the "defeat of the planners" and eliminate the chances that the vision of the "model

\footnotetext{
${ }^{26}$ Marr, 'Spaces of Aspiration, Liberation and Exclusion'. See especially, Chapter Two and Chapter Six for further details on the making of Gaborone.
} 
township" outlined on paper would be realized. ${ }^{27}$ More significantly however, worry over the development of slums in and around Gaborone was not simply a matter of aesthetics.

Government officials sought clearly delineated spatial organization because they believed a legible city - in the sense that it was administratively clear who could be where, why, and under what circumstances - was inevitably a controllable, more easily governed city. ${ }^{28}$ Therefore, regulating who came into Gaborone, whether from rural areas elsewhere in Botswana or abroad, became vitally important.

By the mid-1960s foreigners arriving into what was then Gaberones were already being blamed for both increasing crime and decreasing morality in the new Capital. In an August 1965 interdepartment memo addressed to the Permanent Secretary of Home Affairs, the Commissioner of Police described the following squatter camp scene:

The presence of such large concentrations of unemployed aliens, camp followers, vagrants, and persons without any means of livelihood presents not only a difficult problem to police whose limited resources are stretched to the utmost in investigating complaints [at these areas] of theft, assaults, gambling, illegal liquor brewing, domestic quarrels and faction fights, but is also, I believe, a matter of grave concern to the Health authorities in view of the incidence of disease caused by dirt and inadequate sanitation arrangements....Prostitution, I am advised, is rife and the incidence of venereal disease is on the increase. ${ }^{29}$

Following up on this report, the Commissioner of Police later offered a more succinct assessment of the supposedly degenerative role of foreigners: "Crime generally and the incidence of housebreaking in particular has also increased as a result of the large unemployed alien population in Gaberones." 30 From the perspective of town authorities, these kinds of illicit behaviours represented a dangerous evasion of the government's authority and needed urgent resolution. One of the primary ways employed to tackle the problem was to prevent people from

\footnotetext{
${ }^{27}$ BNA, Department of Public Works (hereafter DPW) BNB 1098, Gaberones Capital Project: Draft Town Plan Report, 1962, 2.

${ }^{28}$ For a fuller discussion of spatial legibility, see: J. C. Scott, Seeing Like a State: How Certain Schemes to Improve the Human Condition Have Failed (New Haven: Yale University Press, 1998); M. de Certeau and S. Rendall (translator), The Practice of Everyday Life (Los Angeles: University of California Press, 1984). De Certeau's chapter "Walking the City" and the discussion of the "theoretical city" it includes is particularly helpful.

${ }^{29}$ BNA, MLGL 1 Box 27, Commissioner of Police, Savingram to the P. S. Ministry of Home Affairs, 26 Aug. 1965.

${ }^{30}$ BNA, MLGL 1 Box 27, Commissioner of Police, Savingram to the P. S. Ministry of Home Affairs, Chief Immigration Officer, P. S. of Local Government, P. S. Ministry of Labour and Social Services, 1 Nov. 1965.
} 
coming into Gaborone in the first place; and when that was not possible, officials attempted to repatriate them to their home villages. These efforts proved futile. One document helplessly observed, "It is realized that once people have been affected by the lure of urban life it is difficult to control their drift to the towns." 31

Yet, if Batswana citizens could not be stopped from settling in Gaborone, it was thought that at least the foreigners could be rounded up and sent home. Government officials hoped that population pressures in Gaborone could be alleviated simply by calling on places like Rhodesia and South Africa to quit dumping their unwanted or undesirables into Botswana who inevitably "swell the ranks of the unemployed." 32 The notion that foreigners were responsible for increased crime, moral degeneration and leeching the limited resources of the State was predicated on the belief that there were some 2,000-4,000 immigrants in Naledi alone. ${ }^{33}$ However, the only available survey of squatter populations taken during this period suggests these figures have been highly inflated. For example, the report notes that only $6.6 \%$ of Naledi's population was foreignborn, and that the overwhelming number of employable males, as well as some women, had some sort of income-generating occupation. ${ }^{34}$ Breaking the numbers down even further, out of the 273 foreigners in Naledi, there were only 10 from Rhodesia and 32 from South Africa (the most represented nation was Zambia, with 138 individuals). ${ }^{35}$ Even when allowing for some measure of fluidity in the numbers, it seems reasonable to conclude that the figures proffered by the government were wildly off the mark. Accurate or not, the statistics relied upon at the time served to exaggerate the level of threat to Gaborone's economic and social viability in the postcolonial period.

Reflecting past apprehensions, similar narratives regarding the presence of foreign populations circulate in contemporary Gaborone. Apart from the fears of "Islams" in Gaborone, and more

\footnotetext{
${ }^{31}$ BNA, MLGL Division C. HA. 21/19 Volume 1, Squatter Problem: Naledi, 1967-1968, Permanent Secretary, Savingram to District Commissioners of Mochudi, Molepolole, and Gaberones, 13 Jan. 1967.

${ }^{32}$ BNA, MLGL Division C. HA. 21/19 Volume 1, Squatter Problem: Naledi, 1967-1968, Commissioner of Police, Savingram to P. S. Ministry of Home Affairs, P. S. Ministry of Labour and Social Services, P. S. Ministry of Local Government, 6 Dec. 1966.

${ }^{33}$ BNA, MLGL 1 Box 27, Savingram to the P. S. Ministry of Home Affairs, 26 Aug. 1965.

${ }^{34}$ BNA, BNB 5316, 1967, Charles Edward Fuller, A Study of the Squatter Population in Gaberones: Undertaken for the Town Council of Gaberones July-August 1967, 3.

${ }^{35}$ Ibid., 3.
} 
recently, the Chinese, much of the current discourse about foreigners in Botswana discusses Zimbabweans in Botswana. Without dwelling on a familiar story, the past decade or so has seen Zimbabwean society convulsed by a confluence of famine, political violence and repression, runaway hyperinflation and a general economic collapse. ${ }^{36}$ Consequently, people have exited Zimbabwe in astoundingly high numbers. Some figures suggest that over one-quarter of Zimbabwe's population of 13 million has left the country. ${ }^{37}$ Particularly popular regional destinations for migrants have been, and continue to be, South Africa and Botswana. While exact figures are difficult to tabulate, one newspaper in Botswana estimates that in 2006 140,000 Zimbabweans were deported from both Botswana and South Africa, with approximately 32,000 removed from Botswana. ${ }^{38}$ The numbers however, are likely to be even higher. Mmegi, Botswana's only privately owned daily paper, estimates that over a six month period in 2006 the number of individuals deported from Francistown is upwards of 30,000. ${ }^{39}$

And these figures only document those who have been caught, meaning that the ebb and flow of people moving across the Zimbabwe-Botswana border is far greater. Indeed, the anecdotal evidence provided in the next section speaks to the ease with which it is possible to move back and forth between the two countries. Uncontrolled transience was such a concern for the government of Botswana that in 2003 it constructed an electrified fence along the border with Zimbabwe in the hopes of preventing the entry of both cattle infected with Foot and Mouth disease, as well as people departing Zimbabwe. ${ }^{40}$ Although the accuracy of these figures remains unknown - they remain fluid "best guesses" - it is safe to say that the numbers of Zimbabweans (temporarily) residing in Botswana is high.

\footnotetext{
${ }^{36}$ For a sampling of recent texts about Zimbabwe, see: D. Potts, “'Restoring Order'? Operation Murambatsvina and the Urban Crisis in Zimbabwe', Journal of Southern African Studies, 32, 4 (June 2006); F. Musoni, 'Operation Murambatsvina and the Politics of Street Vendors in Zimbabwe', Journal of Southern African Studies, 36, 2 (June 2010); M. Bratton and E. Masunungure, 'Popular Reactions to State Repression: Operation Murambatsvina in Zimbabwe', African Affairs, 106, 422 (2007).

${ }^{37}$ D. Pasura, 'A Fractured Transnational Diaspora: The Case of Zimbabweans in Britain', International Migration, (2011), 6.

${ }^{38}$ Sunday Standard, 'Botswana, South Africa Deport 140,000 Zimbabweans in 2006, Police', 29 Jan. 2007 $<$ http://sundaystandard.info/print.php?NewsID=929> (29 Jan. 2007).

${ }^{39}$ Mmegi, 'The Neighbourly-Burden that is Zimbabwe', 26 Oct. 2006 <http://www.mmegi.bw/2006/October/Thursday26/9976358061774.html> (26 Oct. 2006). The figures presented in the popular press seem to reflect demographic trends identified in the literature on Zimbabwean migration into Botswana. One scholar shows that while in 1997 8,465 Zimbabweans were deported from Botswana, by 2002 the number had jumped to 26,585. See: E. Campbell, 'Reflections on Illegal Immigration in Botswana and South Africa', African Population Studies, 21, 2 (2006).

${ }^{40}$ W. Brown, Walled States, Waning Sovereignty (New York: Zone Books, 2010), 19.
} 
Given the above numbers, it is perhaps not surprising to discover that Zimbabweans are thought to be everywhere in Botswana. The popular perception continues to envision Zimbabweans as draining the country's resources on the one hand, and contaminating the local population with previously absent levels of delinquency and immorality on the other. ${ }^{41}$ Not all people in Botswana, however, fully buy into this story. A longtime expatriate policymaker estimated for example, that in light of the approximately 100 instances of crime per day in his Gaborone West neighbourhood, it is increasingly difficult for Batswana to attribute blame solely on outsiders. Another Motswana resident of Gaborone, while not denying that Batswana contribute to heightened crime levels, went on to argue that Batswana were overly susceptible to the negative influence of outsiders because, as she put it, "we like copying." Others however, adopt a harsher stance. One University student noted that in their need to hustle to survive in Gaborone, Zimbabweans had "become animals." Another identified a specific comparison: "These people [Zimbabweans] behave like horses." A third pronounced, "this has to stop: slaves beating their masters." He went on to argue that even if it was true that most Zimbabweans don't cause problems, how do you filter the troublemakers? It was then, best to keep them all out.

Voicing broader demographic concerns, the Main Mall vendor who earlier feared the overwhelming presence of "Islams" in Gaborone provides a similarly - fantastically so - high estimate of the numbers of Zimbabweans. He asserts, "They are three million. We are 1.7 million. That is too many." Minutes later, determined to emphasize the pervasiveness of Zimbabweans, he claimed that when in a crowd today, "If you are with ten [people], only two will be Batswana." The accuracy of the figures seems less important than the fact that they are articulated at all as they seem to reflect a feeling of demographic, political or economic instability. As one University of Botswana student put it, comparing President Mugabe and then Vice President Ian Khama, "Botswana will become like Zimbabwe and Zambia" after Khama becomes President. This is not an isolated opinion in contemporary Botswana, as many people seem a lot less certain about Botswana's future than they might have in the recent past. At the same time, these uncertainties do not prevent people from challenging the notion of collective victimhood by speaking of a time when Batswana will fight back against those perceived as

\footnotetext{
${ }^{41}$ Marr, 'If You are With Ten, Only Two will be Batswana'.
} 
oppressors or threats. Referring to the Indian ownership of shops around Gaborone, one street vendor predicted that after I've returned to the United States, "Someday [I] will hear that Batswana has (sic) fought back and burned all their shops....It will happen." Similarly, a mostly unemployed guy in his early 20 s echoed this sentiment while sitting under a tree in Old Naledi ${ }^{42}$, plainly stating, "I'm like Mugabe when it comes to white people."

Before continuing onto the next section, a few points regarding current immigrant narratives ought to be made. Contrasting the perception of claustrophobia amongst contemporary residents of Gaborone with the reality on the ground is not intended to diminish the unease Batswana feel, nor minimize the challenges presented by the high volume of Zimbabweans who have crossed into Botswana in recent years. Instead, an investigation of the "talk" about Zimbabweans and other foreigners offers a glimpse into insecurities that resonate across Botswana's society. ${ }^{43}$ Indeed, as Luise White argues, it is crucial to locate these narratives in the specific temporal and geographic context in which they are embedded. ${ }^{44}$ Furthermore, if it is true that gossip presents the social values of the gossiper, while rumors say something about a shared "intellectual world of fears and fantasies, ideas and claims..." it might be possible tease out just what values and apprehensions are being reflected or shared. ${ }^{45}$ And if it is possible, the task then becomes to interpret what issues they speak to, and what their significance might be.

To that end, I would like to assert a connection to the earlier discussion of everyday biopolitics and autochthonic discourse as one possible lens through which to consider these stories. Perhaps what is significant here is not to discover what these stories mean, how they function or the

\footnotetext{
${ }^{42}$ Old Naledi is the former squatter camp noted earlier in the text as the site of the riot between Batswana and Rhodesian laborers. Into the 1970s the government tried to demolish the neighbourhood and relocate its residents elsewhere without much success. By the latter part of the decade, the government had given up these policies and recognized Old Naledi's right to exist. Today, Old Naledi is both a vibrant neighbourhood but also the largest lowincome area in Gaborone.

${ }^{43}$ Jean and John Comaroff make similar points as they try to reconcile the linkages between the realities of crime in South Africa and how it is experienced in different narrative forms. They note that the encounter with crime in the media, for example, "morph from incidents to incidence, read in the public mind as the state of the nation, as the law in disorder, as a world under threat. Thus it is that numbers [e.g. crime statistics] become a vehicle for the experience of the unreal, an experience that transforms the abstract into the sensate, the unknowable into the known." Please see: J. Comaroff and J. Comaroff, 'Figuring Crime: Quantifacts and the Production of the Unreal', Public Culture, 18, 1 (2006), 221.

${ }^{44}$ L. White, Speaking with Vampires: Rumor and history in colonial Africa (Berkeley: University of California Press, 2000), 58.

${ }^{45}$ Ibid., 59; 86.
} 
mechanisms by which they are disseminated, but rather to examine what forms of state power they make possible. Stories and stereotypes "from below" condition what happens on the ground and to what extent the exercise of authority occurs. The successful implementation of a particular biopolitical objective - categorizing those who belong in the population, from those who don't; separating out those who are normal from those who are deviant - ultimately depends on the circulation of, and adherence to, these narratives. Indeed, as Schinkel makes clear, only some of the techniques deployed to manage or cultivate the population come from the state. ${ }^{46}$ Informal stories told about immigrants thus become a crucial component of the project to trace the contours of society and pinpoint those individuals or groups that present a political, economic, or even an existential threat. What I show in the following section however, is that these categorizations are fluid and that the accompanying exercise of authority is irregular and performative; sometimes it is both. I elaborate on these assertions in the concluding section.

Stories about foreigners in Botswana, and in particular stories about Zimbabweans, are not new to Gaborone. Zimbabweans-as-other are blamed for stealing jobs or women, and for injecting into the (moral) body politic all manner of degenerative behaviors, ranging from crime to promiscuity. These stereotypes, rumors and attributions might reflect quite real worries about political, social or economic insecurity. At the same time though, they are also not without a cost to the people on which they are affixed. As a Zimbabwean friend told me while complaining about the few days remaining on her passport, "Sometimes I wish I wasn't Zimbabwean." With those sentiments in mind, here I switch gears to tell to another side of the story of Zimbabweans in Botswana. What is the daily experience of some of the people who live in relation to elaborate backdrop of "anti" rhetoric and policing? And conversely, might we glean any insight into what everyday policing tell us the performance of the state and its ability to project authority? How do Zimbabweans respond to their stereotyping? Perhaps most important to understanding these everyday interactions, to what extent are these categorizations mutable?

\section{Down on the Corner: A View from the Street}

\footnotetext{
${ }^{46}$ Schinkel, 'From Zoepolitics to Biopolitics', 164.
} 
How do these citizen/stranger dynamics play out on the ground? Occasionally, as in the averted mob violence from 1965, these tensions crescendo into violent outbursts. One such instance was the brief riot at the Gaborone bus station between Batswana and Zimbabweans, labeled a "war" in the local media. ${ }^{47}$ More often though, the struggles are far less dramatic, played out in the more mundane theatre of the everyday. One of the primary sites of interaction between Batswana, Zimbabweans, and the police is located on the street corners of the Gaborone neighbourhood known as White City. The neighbourhood, named for the small low-cost houses hastily painted white in the final days of Gaborone's construction in the mid-1960s, is today well-known in Gaborone and Zimbabwe as a site where Zimbabwean immigrants - along with a smattering of individuals from other countries in the region-daily come to look for short-term "piece jobs" such as washing, gardening or construction. For those familiar with the area, the neighborhood has therefore acquired new names, such as "Bulawayo" or "Little Zimbabwe," which better reflect its current demographic notoriety.

For many Zimbabweans seeking work in White City, Botswana was seen as their best short-term hope for both escaping Zimbabwe's crushing inflation and unemployment in order to raise money for the family members who remained behind. One job seeker described the dire situation back in Zimbabwe: "It is not a country now. It is a like a game park. It is not a suitable place for people to live." Another said President Mugabe's regime "is like a plane with no fuel and with no place to land. The options are to jump out and die, or glide and see what happens. You will crash eventually, [but] we are now just seeing how long he will glide."48

\footnotetext{
${ }^{47}$ B. Gabotlale, 'Bus Rank Business Counts Losses After 'War', Mmegi, 6 May 2004, 9; Mmegi, 'This Xenophobic Behavior Must Stop', 5 May 2004 < http://www.mmegi.bw/2004/May/Wednesday5/10680060701279.html> (24 Jan. 2006).

${ }^{48}$ Here is perhaps an appropriate moment to give some insight into the ethnographic data collected for this essay, along with a mention of the circumstances under which it was gathered. I conducted fieldwork in Gaborone for approximately eighteen months from February 2004 to July 2005, spending the last few months of my time there working in White City. As it happened, this turned out to be an exceptionally tense period for those looking for work on-the-corner, since the fieldwork coincided with the onset and immediate aftermath of the Mugabe government's Operation Murambatsvina. For the Zimbabweans in White City, who already had a difficult time getting by, the events unfolding back home added to the pressure. Conducting research under these conditions, in which there was, at times, a palpable atmosphere of worry, unease and suspicion required me to be especially sensitive to how I worked and engaged people in White City. Considering the political animosity and violence in Zimbabwe, people seemed to feel a need to be cautious of what they said around strangers, in groups, or around me. Indeed, I was respectfully warned early to be careful about asking overly political questions for two reasons. On the one hand, it wasn't clear who might be a spy or informer, while on the other, I even might be considered an agent of the Mugabe government asking questions in order to get people to incriminate themselves. For this reason, I often
} 
The bleak political and economic conditions in Zimbabwe have left many former students and those with professional training scrambling for jobs on the economy's margins. The very public struggle to obtain work in Zimbabwe was a source of shame for some. ${ }^{49}$ One recent arrival explained, "It is embarrassing to do labouring at home [in Zimbabwe]. People will see you. You who went to University and now you are doing construction? It is better to come to Botswana where people don't know you." And so, people formerly employed as skilled workers, teachers or nurses in Zimbabwe, arrived in Botswana to subsist as day laborers or domestic help, assuming they were hired at all. Still, for some Zimbabweans, such as my research assistant Ruth, who relied on a long established network of friends and family while in Gaborone, to daily stand on a street corner - even if in another country, surrounded largely by strangers represented a low form of behavior. Speaking of the White City locales frequented by Zimbabweans, “This is an ugly place. It has a bad name. I wouldn't even want to walk by this place. To sit here all day, I don't like what they are doing. But people know I am here on research so it is okay."

For many new arrivals, who've heard about this place from people they knew back home, White City is a place of last resort. One Zimbabwean male who came to White City in search of work emphasized the desperation, the pure randomness inherent in their day-to-day predicament. Responding to a question about how things are going, he told me,

Things are not okay. As you can see. We come here at the earliest, six[am], when it is dark and very cold. To stand here and wait. And for what?...We get here at the earliest, at six and we don't know what is going to happen.

Some, they get here at ten and they get jobs. And we are here all day and have nothing.

Much of the activity occurs on the street corner entrances leading into White City's residential interior, where the car traffic is heaviest, visibility is highest, and the odds that the occupant of a passing car might stop are best. Conversely, areas of increased car traffic attract a greater

didn't collect names of the people with whom I spoke. For better or worse, this anonymity is reproduced, with a few exceptions, in the text that follows, even in those occasions when someone volunteered their identity.

${ }^{49}$ This observation is confirmed in other work on the Zimbabwean diaspora. JoAnn McGregor, for example, found that Zimbabwean migrants in Britain who engage in similar forms of "low" work express similar sentiments. See: J. McGregor, 'Abject Spaces, Transnational Calculations: Zimbabweans in Britain Navigating Work, Class and the Law', Transactions of the Institute of British Geographers, 33, 4 (2008), 473. 
density of job seekers. One of the busiest locations is situated along a busy road dividing White City from the Government Enclave. Overlooking the proceedings is the Orapa House complex, where the diamonds mined in Botswana are collected before being shipped to South Africa for further processing. Here, Zimbabweans wait for hours in a dusty open space, used as a public lot or informal driving school, in the hopes that a car will stop and a job will be offered. Deeper into the White City, Zimbabweans also congregate on less-traveled residential streets. In these areas adjacent to the property lines of private houses, the competition for jobs is less, but so is the number of opportunities.

The rhythms of waiting for work do not deviate much, day after day. Starting early in the morning and often lasting into the late afternoon, the day's activities variously involve periods of sitting, standing, avoiding the afternoon sun, seeking out the morning sun during Botswana's chilly winter mornings, shielding your eyes from dust and discarded plastic bags kicked up by the wind, chatting, laughing, arguing, gossiping and analyzing current events ranging from China's increasing involvement in Africa to detailed accounts of the Michael Jackson molestation trial to wondering about impending interventions in the southern Africa by the Western military forces. As someone asked me, "Is it true that there are Americans in Botswana ready to invade Zimbabwe? Mugabe says so.” Apart from talking, for the more assertive, each day involves hustling for a few Pula to buy a bit of food or a carton of "Shake Shake"/Chibuku sorghum beer.

Occasionally interrupting the flow of the day, a car would pause on the side of the road, while at other times, the vehicle would only slow down, prompting running negotiations between the car's occupants and the people trying to keep up. The appearance of a stopping car caused most Zimbabweans in the vicinity to crowd around the open window hawking often exaggerated (if not alright falsified) qualifications. Competition for employment could be fierce, but never, as far as I was able to tell, did it turn aggressive or violent. In one typical encounter a truck pulled over onto the shoulder and a group of 10-12 men drew close to the driver's side. Pushing and shoving to attract the driver's attention to themselves, since only one worker was needed, the men jostled for a position close to the potential employer's ear. After a few minutes of overlapping shouts and confusion the exasperated driver tells everyone to back up and go - he 
does not need anyone anymore, no one gets hired. As the truck drives off, one of the group walks past me and with a slightly wry smile says, "You see what happens?"

After a car departed, whether anyone was picked up or not, the jokes and laughter tended to return. Most times cars would simply pass by, though the more courteous drivers would place their arm out the window, palm up, and shake it back and forth to indicate "no job." The relative good humour with which the competition unfolds is perhaps surprising considering the fact that most Zimbabweans have concluded that the once high demand for manual labor has collapsed as the building boom of the early 2000s ended. A laborer I frequently encountered in White City suggested that "there is no difference between [Gaborone] and Zimbabwe. It is tough for Batswana too....There used to be many piece jobs, but now there are none." On a separate occasion, while listing the reasons for the decline in the labor market, he declared: "I've come to White City at the wrong time." And even when jobs are available, pay is extremely low. One White City regular claimed that a full day's construction work would net you 21.50 Pula ${ }^{50}$, which he noted, was barely enough to survive on, and that is if you were fortunate enough to be hired each day.

Weighing opportunities as to where the best chance to land a job might be however, is not the only criteria determining where people decide to stand away the day. Crucial to the daily routine is the selection of a spot with enough avenues for escape to avoid the constant police presence, or more infrequently, a large-scale round-up of Zimbabweans. The area across from the Orapa House offers many possibilities for escape, while street corners in the interior present more limited options due to the walls built around private houses. Ideally, one woman tells me, people will try to spread out and not congregate together in one or two places because that means there are more eyes on the lookout for the police - if you see people running in the distance, you can presume that the police are nearby and headed in your direction. Another explained the decision of many to sit in the blistering midday sun rather than wait in the shade: it can be dangerous to "sit in the shade because when you are relaxed, that is when the cops come. It is better to be uncomfortable in the sun." And as someone who chose a more risky spot, with a limited vantage point from which to watch the movements of others, simply put it, there is "no reward with no

\footnotetext{
${ }^{50}$ Approximately four USD during the time this conversation occurred (June 2005).
} 
risk." Being-on-the-corner for a Zimbabwean job-seeker therefore requires a balance between visibility to potential employers along with the need to maintain a low profile in order to evade the police presence frequently patrolling the area. The most common form of patrol occurs on foot, policemen in twos or threes walking the beat, appearing as often as a few times an hour or as little as once or twice a day. A slow day on the corner is, therefore, periodically punctuated by bursts of activity as people move to hide from the police.

In the open spaces of the Orapa House corner, uniformed patrolmen in their deep blue uniforms are often visible from distances of hundreds of yards. ${ }^{51}$ In those rare instances where the police were not immediately visible, loud whistling heard in the distance or the sight of some people running towards your position with their wrists crossed (evoking a policeman's handcuffs) were enough to indicate that it was probably a good time to move. Indeed, one of the common practical jokes pranksters would play on newcomers to the corner was to begin running away in a panic, setting off the newbies. The guys who initiated the joke would stop running after a short distance and burst out laughing, along with all the folks who knew better.

Apart from jokes intentionally made, there was also a joke like quality to the interaction of the police and the Zimbabweans. One long-time resident of Gaborone dismissed the raids as a "joke everybody is in on." And really, there was a dimension of phoniness, of going through the motions merely for the sake of appearances. A typical episode would begin with the police appearing in the distance, proceeding to casually walk toward a large group of Zimbabweans. A group of Zimbabweans with whom I had been talking, for example, having seen the approaching authorities, would bid me a "so long" and then slowly move off in a variety of directions — some melting away into the neighborhood, others ducking into one of the front-yard Chibuku bars, others heading toward the crowds of the nearby bus-station, the bravest wading into the street's busy traffic, dodging combis and private taxis. ${ }^{52}$ The police would pass through, almost always without pausing to question anyone who might be around, and disappear around a corner only to

\footnotetext{
${ }^{51}$ Undercover officers are usually floating around too, but their presence is a poorly kept secret among most Zimbabweans. As were the Batswana residents of the neighborhood who acted as citizen informers for the police. ${ }^{52}$ Walking into traffic is made even more dangerous by the fact that combi drivers would sometimes attempt to run over suspected Zimbabweans running away from the police.
} 
reappear later in the day. Usually within a minute or two of their departure, most everybody would head back to retake their street corner positions.

There was little drama in these small displays of authority and evasion, rather, most seemed rather disinterested, playing long familiar roles in a bit of public theater. One Zimbabwean referred to the daily routine as an unending game of "cat and mouse with the police." Indeed, a beat cop who patrolled the neighborhood on a regular basis admitted that "yes, it does get boring" chasing Zimbabweans day after day. But has been noted elsewhere, when dealing with the most marginal of undocumented immigrants, the authorities will make a show-even if it is half-hearted as in this instance — of force if only to enforce the "illusion" of the State's ability to perform effectively. ${ }^{53}$ The Zimbabweans recognize the underlying superficiality of the displays of most police patrols. One man tells me that for the police walking the street, they aren't really interested in making arrests, rather they "just want to see how we react. Whether we fear them or not." This recognition, seemingly shared by both Zimbabweans and the police tasked with scrutinizing their behavior, is a crucial point for how to understand the challenges confronting a functional deployment of biopolitics. The everyday policing of spaces is both a demonstration of authority that at the same time remains highly theatrical. In the same way that border fences represent spectacle ${ }^{54}$, the ongoing patrols in White City point to a similar notion of a performative policing, in which nothing ever really seems to happen. People circulate within the spaces of the city, move back and forth between borders, but more often than not, the status quo is unchanged: Zimbabweans are still there, every morning.

Ultimately, then, perhaps the purpose of this security routine is the policing of what is appropriately visible on the streets of Gaborone. That is, the "problem" won't really be "solved", but there will be a show of trying to do something. Raids on immigrants, whether in White City or elsewhere, become a superficial way to "cleanse" society. ${ }^{55}$ The crime being policed in the streets of White City is that of loitering or "idling," so that the visibility of the Zimbabwean in Gaborone might be effaced, along with the very public reminder of the

\footnotetext{
${ }^{53}$ Comaroff and Comaroff, 'Naturing the nation', 648.

${ }^{54}$ Brown, Walled States, Waning Sovereignty, 25.

${ }^{55}$ P. K. Rajaram and C. Grundy-Warr, 'The Irregular Migrant as Homo Sacer: Migration and Detention in Australia, Malaysia, and Thailand', International Migration, 42, 1 (2004), 56.
} 
government's impotence in dealing with the "problem."56 One police officer resting on a concrete slab on the Orapa House corner, taking a break from his foot patrol, warns me to be wary of the Zimbabwean "rude boys" who will rob me of my money and cell phone.

Furthermore, he informs me that this area must be kept clear of people, since Zimbabweans will commit crimes during the day and engage in "immoral activities" once the sun goes down. Another officer talking about Zimbabweans in White City, "These people are causing us big problems....They are like wild animals. They don't behave sharp." For thieves in Gaborone, "the people who are ruling Botswana," White City is "their office," says a Motswana woman who works as a clerk in a neighborhood shop. A police officer accosting a group of Zimbabweans tells them, "This is not a hotel. You cannot stay here." Pointing to me though, I was allowed to remain in the same spot, continuing to "idle." A different day, officers approached Ruth and I to ask what I was doing in White City with "this Zimbabwean". After explaining what I was up to, one of the police officers went on to explain that "these people can't be here. They come and sit all day and someone will come and [pointing to Ruth's purse] one of these boys will come steal a bag like that and how can we find them? We can't let them stay in groups." The Zimbabweans I encountered were of course, not oblivious to the fact that the authorities were trying to control their movements on Gaborone's streets. The police would tell them that White City was a no go area for Zimbabweans, but, they would ask, "Where are the signs?"

The fact that I was, time and time again, allowed to remain in the same place, calls into the question the claim that the police are concerned mostly with disrupting criminal behavior by breaking up congregations of loiterers. It became clear, in other words, that loitering was not the so-called crime with which the authorities were worried. In her ethnography of Costa Rican plazas, Low describes how the same behaviors are given different meaning depending on the people performing them. ${ }^{57}$ On White City streets, this was especially true of sitting and standing, the crime of idling. A long exchange with a Zimbabwean job-seeker about life in Gaborone was

\footnotetext{
${ }^{56}$ An alternative, or maybe complementary, explanation for the necessity of "cleans[ing]" space in this way is that in the everyday struggles of Zimbabweans, residents of Gaborone might perceive a glimpse into their own uncertain social, political and economic future. In a time of high rates of poverty, unemployment and a slow erosion of political rights in Botswana, the symbology of Zimbabweans-on-the-street could invite people to reflect on the trajectories of both themselves and the nation.

${ }^{57}$ S. Low, On the Plaza: The Politics of Public Space and Culture (Austin: University of Texas Press, 2000), 174175 .
} 
summed up with the statement: "It is a crime to be a Zimbabwean." Sitting, standing, walking; it didn't really matter, being Zimbabwean made you fair game to the police. Zimbabweans pointed to the fact that Batswana criminals in White City were left alone by the police while Zimbabweans were, in their opinion, unfairly singled out. On the White City locations I frequented, Batswana were perceived to be selling stolen goods to Zimbabweans. Yet, it was the buyers of stolen merchandise, especially cell phones, who were often the focus of police attention. "These [thieves] are Batswana," I was told, "In fact, if the police catch them, they will take the police back to the people they sold [stolen goods] to and then the police will let the thieves go and arrest the person who bought the stolen goods. Asking 'how can you buy without seeing a receipt?"' I witnessed this bias firsthand as well: a small skirmish between some Batswana and Zimbabweans, in which rocks and pipes were displayed as weapons, ended with the arrival of the police, who told the Batswana to go while the Zimbabweans involved were arrested.

Over the course of the research I experienced firsthand the variability in which the rules for being in White City or the expectations of belonging were enforced. As I noted above, I was initially allowed to "idle" with few questions asked by the authorities. Indeed, in their patrols around the area, they would often come and chat with me for a few minutes before continuing their rounds. I functioned as a welcome distraction, perhaps I was even perceived as an equal or a confidant with whom they could discuss, and find a sympathetic ear, the Zimbabwean "problem". I could, therefore, sit curbside or on pieces of broken concrete, or circulate amongst different groups as I pleased.

During one of my first days in White City attempted to make sense of what to my mind was an obvious discrepancy. I asked some of my Zimbabwean informants why I was allowed to remain loitering in the streets while they were made to leave, or worse. They expressed surprise at my asking such an easily answered question. "Ah, they respect your skin color." I would go further: it wasn't merely the fact that I was white, but also male, American and in use of a wheelchair. I was both clearly out of place and not Zimbabwean in any number of ways. However, as the novelty of my appearances diminished, the visible markers of race, class, and nation that initially set me apart mattered less and less. By virtue of the time I spent on-the-corner, hanging out with 
Zimbabweans, sharing a laugh or a lunch or a beer, the more I became associated with them and the challenge to the authorities' notion of spatial and civic order they represented. Indeed, by the end of my time working in the neighborhood, I was just as likely to be hassled as the Zimbabweans who frequented the White City street corners. Just as other Zimbabweans in White City, by the end of my research in the neighborhood, I too had a place to "vanish" to when the police appeared - an informal hair braiding salon owned by a Motswana friend of my research assistant. By no means am I implying that I became "Zimbabwean" or reached their level of public vulnerability. ${ }^{58}$ Instead, I want to suggest that my transformation points to a certain amount of fluidity in notions of citizenship and identity, meaning that there is some ambiguity in norms of inclusion or exclusion. These expectations, and the rules governing their implementation, are perhaps dependent on everyday behaviors, perceptions and the uses of space. That is, determinations of belonging and the enforcement of rules regarding who can "idle" and who cannot, depend on how they are performed or enacted in mundane activities and encounters. I will return to these speculations in the concluding section of the text.

While most times, cops on the beat created predictable, manageable difficulties, far more worrisome for Zimbabweans, were patrols carried out by the SSG (Special Support Guard) who are spoken of by Zimbabweans as an especially brutal paramilitary arm of Botswana's security apparatus. Existing in a gray area between the police and the military, the SSG were deployed for more difficult or dangerous policing operations. Though far less visible than the regular police, an appearance by the SSG immediately dissipated any possible levity in the usual cat and mouse game occurring in White City. During a typical SSG sweep, a large open air trucknicknamed a "Six-Pack", capable of disgorging a contingent of officers - would converge on an area. People unlucky enough to be in the vicinity would be rounded up. Rumors detailing the violence perpetrated by the SSG abounded. One Zimbabwean relayed a story to me about what happened to one individual caught without a passport. The regular police will take you to the police station, he explained, but the SSG prefers to just beat you. With this particular boy, "They

\footnotetext{
${ }^{58}$ One afternoon it got particularly dodgy on the street corner where I was working. On that occasion, I was nearly arrested and my research confiscated. While one of the plainclothes officers read some of my notes back to me, he asked with a visceral sneer, "Why is this interesting to you?" As part of my last-ditch effort to talk my way out of trouble, I showed the group of officers my U.S. State Department identity card. And after some deliberation they gave me back my notebook and told me to leave. Obviously the others on the street corner didn't have that luxury. From then on, having learned my lesson, when more than 2 patrol officers appeared, I took my leave from where I was, and disappeared along with everybody else.
} 
[SSG officers] hit and hit, until he couldn't speak or eat. All he could do is open his eyes and bleed. He died yesterday....The Botswana Government must teach the SSGs not to beat people." However, not all treatment was so harsh. Describing a night raid in the Bontleng compound in which she stayed, an older woman with a plastic right leg narrated the following scene: "The police came to my house. And when they came I took my leg and threw it away. The police were shocked, 'We didn't know you were like this,' they said. I told them, 'Okay. Carry me on your back to jail. I can't walk.' They apologized and went away."

More often than not, once caught, immigrants are given the option of receiving a small number of lashes (anywhere from three to five) from the customary court, a short jail sentence (up to three months), or payment of a P100 fine. Since a P100 fine remained outside the financial reach of most Zimbabweans immigrants in Gaborone, most opted for the lashes or jail sentence. At other times, when larger numbers of individuals have been caught by the police, the authorities will simply conduct mass deportations. A day long trip to the border on the gumbakumba, ${ }^{59}$ the large armored truck capable of legally carrying 150 standing Zimbabweans, but known to carry up to twice as many bodies, is seen by most people I talked to as the least bad option. For those who want to remain in Botswana after being deposited back in Zimbabwe, re-jumping the border is easily accomplished, "If you get deported at two you can be back across the border at half two," one Zimbabwean who frequently moved between the countries told me. Even if the trip on the gumbakumba requires a stopover at a Francistown prison facility known for housing illegal immigrants, that isn't necessarily a bad thing. One woman described the prison's environment as "being better than a cell here in town. It is just like [a] house: there is food, a bed, water to bathe with. The only difference is that you are not free to go, there is a big fence and the police."60 A Zambian male illegally in Botswana, caught in the White City, threw away his passport in order to continue to claim he was from Zimbabwe, knowing that if he could successfully argue he was a Zimbabwean, his deportation would be expedited through the bureaucratic machinery. There are, on occasion, some advantages to being a "Zimbabwean" in White City during interactions with the authorities.

\footnotetext{
${ }^{59}$ This term was explained to me as meaning "big thing."

${ }^{60}$ The holding center was built at a cost of P49 million (\$9.8 million USD) and can accommodate up to 500 people in both separate male and female quarters. See: Campbell, 'Illegal Immigrants in Botswana'.
} 
Apart from looking for employment and evading the ever-lurking beat cops and SSG "6-packs" rumbling across White City's dusty interior streets, much of the activity occurring on the neighborhood's corners revolved around talking, debating, and gossiping. For many Zimbabweans, their treatment in Botswana is seen as "humiliating" because they are caricatured as "animals" or as "children." Criticizing their coverage in the media, a Zimbabwean man says they are treated unfairly. He explains to me that photographers will come and take pictures of them running from the police, and the next day, the headline will say something like, "'Illegal Immigrants out of Control." Another complains, "I am not a criminal, but they treat me like one." On a different day a similar sentiment is expressed: “Batswana don't treat us very well here. They are treating every Zimbabwean like we are thieves." Indeed, many scoff at the popular contention that Zimbabweans have taught Batswana how to become criminals.

Batswana often steal, but when caught, a Zimbabwean woman sitting next to me on a White City street corner explains, "They will say that a Zimbabwean taught them." Dismissing the blame, she continues, "Before we came here there were big jails in Botswana: mo Mahalapye, mo Francistown. Who are these jails for? They say Zimbabweans are stealing, but it's all lies....You can't teach people things if they don't want to learn them."

Aware of their unflattering portrayal in public discourse, the Zimbabweans who eke out a living on White City's streets circulate their own counter-narrative about the perceived failings and character flaws of Botswana citizens. ${ }^{61}$ The general consensus seems to be that while they are willing to work for Batswana they don't have to like them. Some of the stories told about Batswana imply that they are predisposed to immoral behavior. If the police arrest Zimbabwean women, they will be "touching their private parts, abusing them." Going even further, others describe Zimbabwean job-seekers who are murdered and mutilated by their Batswana employers.

Some of the people who are taken [for piece-jobs], especially the women, will be abused. They will be killed for business: they will take their heads and their hearts. The heads are used for fishing in South Africa. The hearts are used for medicine. This is happening here [in Gaborone]. Some of the women are raped. They risk their lives because they need money....Sometimes you are paid an amount less than what we agreed on. And if you complain they will take you to the police. We are lacking civil rights. We need civil rights.

\footnotetext{
${ }^{61}$ For another example in a South African context, see: L. B. Landau, 'Transplants and Transients: Idioms of Belonging and Dislocation in Inner-City Johannesburg', African Studies Review, 49, 2 (September 2006), 139.
} 
However extreme the beginning portion of the above scenario seems, it speaks to the frustration and feeling of helplessness experienced by many Zimbabweans looking for work in White City. People on the street are perplexed at the amount of energy expended pursuing Zimbabweans: "They spend all their time chasing Zimbabweans for nothing," when "we have to eat, to get bus fare, to pay rent."

They feel as if they are being taken advantage of: economically, morally, physically. For many, their marginal status in Gaborone is seen as especially degrading because they see Batswana as inferior or less civilized than Zimbabweans. Surveying their White City surroundings, two women point to a nearby two-room house, one of the original dwellings in the neighborhood. One exclaims, "Look at these houses! These are bad. In Zimbabwe, our houses are so nice. Even a bad house like this will have plumbing and a flush toilet." Another afternoon, a similar view is expressed by a new arrival from Zimbabwe, "Botswana is not an interesting place to stay. It is not hygienic. No bath. No proper bath. Pit toilets. Not like in our own country. Whether you are rich or poor, you will have decent showers and toilets. Here it is like you are in the rural areas. It is too unhygienic. It is only because we need money we are here. Not because we like it." $" 62$

A second common refrain amongst the Zimbabweans is that Batswana are an unintelligent people. One university student who studied microbiology before having to drop out of school thought that Batswana didn't like Zimbabweans because Batswana are “illiterate”, while another man offered a more essentialized assessment, "Batswana are weak. Weak physically, mentally, emotionally." Speaking of Batswana, a man from Harare says that their lack of education might explain the poor relations between citizens of the two countries, "They are not educated. They don't know how to interact with other people.... They might not talk to you, but not because they don't want to talk to you but because they don't know how to speak English.” Another man says

\footnotetext{
${ }^{62}$ The critique of Botswana as not being "developed" can be traced back to colonial standards of housing and urban planning. One recent article observes that for many Zimbabweans - at least initially - could see Operation Murambatsvina as legitimate due to the fact that fulfilled people's long-held expectations of the government's duty to make streets and residential areas cleaner and safer. See: J. Fontein, 'Anticipating the Tsunami: Rumours, Planning and the Arbitrary State in Zimbabwe', Africa: The Journal of the International Africa Institute, 79, 3 (2009), 379-381.
} 
that in comparison to Zimbabwe's cities, Gaborone's town plan is totally disorganized: “if you don't have a phone number, you will get lost." He continues, "In Zimbabwe, people are much more civilized. Here you can find someone from the young generation, 15, 16, years old and they can't speak a word of English."

Many people tell stories about having outwitted Batswana, especially their immigration and police officers. One woman says while waiting for a washing job, "These Batswana are stupid." She elaborates by describing easily tricked, illiterate immigration officials who need Zimbabweans to read their passports or point out the appropriate stamps. On a different occasion, I observed my research assistant get away with showing the police illegitimate documentation. While taking notes one morning, two police officers came to where we were sitting to ask what we were doing. After questioning me about what I was doing and writing in my notebook, they turned their attention to Ruth, demanding to see her papers. Reaching into her handbag, she pulled out a tattered sheet of paper and gave it to the officer. He studied the document for a minute, handed it back to her, and instructed her to get the paper laminated. With that, the pair walked off. Once they were a safe distance away, Ruth showed me the paper she gave to the cops. Printed on the top of the sheet in bold blacks letters, was the phrase "Emergency Travel Document." Issued by the Zimbabwean government, it granted her permission to travel to Botswana (and South Africa). Laughing at the policeman's inability to distinguish between documentation from Botswana and Zimbabwe she tells me, "These are so stupid. They are fooled by the picture [the seal of the Zimbabwean government] and stamps."

It is possible to draw to conclusions from this example. On the one hand, while this is more an example of shoddy police work rather than proof of an innate lack of mental capacity, it again speaks to the limitations of biopolitics and the policing of "problem" populations. At the same time, it is likely that these stories and episodes provide a way for Zimbabweans to subvert the authority, recapturing some control over their circumstances while reclaiming a personal pride. In the same way, fantasies are created stating that they are more compassionate and caring than Batswana. 
One Zimbabwean woman tells a sympathetic crowd that her Batswana employers would eat in front of her without offering her anything. Confirming this point of view a man in the crowd spoke out, "Batswana think Zimbabweans are not human beings...Even a security guard will ask you for your passport." He continues, concluding with what he suggests to be the ultimate condemnation of Batswana, "In Zimbabwe, if you ask for water, they will give you water." On a different day, the typical Zimbabwean experience in Gaborone was thusly summed up, "Batswana? They don't want us here. They hate us. They treat us like dogs."

\section{Conclusion}

I began this essay by discussing the Batswana perception of immigrants from both historical and contemporary vantage points. In the second half of the text I sought to contrast the "talk" about Zimbabweans by sketching the everyday experiences of migrant jobseekers on the streets of White City. Complementary to the portrait of struggles, anxieties and challenges today confronting Zimbabweans and Batswana, the themes of identity, power and the state have been recurrent throughout. I would like to close the piece, then, with a few final thoughts related to these points.

As noted above, there is often a pervasive theatricality to the policing of space and people on the streets of White City. The script of the "cat and mouse game" is both familiar and adhered to with minimal deviation. On the one hand, perhaps this is attributable to the fact that the goal of these efforts is less a solution than it is a demonstration of state power. ${ }^{63}$ A sort of policing as kabuki dance, in which the inability of the state to effectively "cleanse" its streets or purify its population is masked by a high degree of visibility in the form of uniformed officers. At the same time though, the story of the White City told here articulates the difficulty of actualizing biopolitical power on the ground due to not only the limitations of the state, but also because of the discursive and spatial ambiguity in which it and its agents must operate. That is, who can be where, why and under what circumstances is never clear in practice.

\footnotetext{
${ }^{63}$ Marinaro, 'Between Surveillance and Exile', 282.
} 
In White City, the extensity of the state remains uncertain, variable and uneven. Under these conditions of marginality the mechanisms of "state power" must be ceaselessly "reestablished."64 At these borders between state/not-state or citizen/not-citizen or normal/not-normal labels and collapse, become fuzzy. Anna Tsing refers to these "zones of unpredictability" or margins as "sites from which we see the instability of social categories." 65 When categorizations are unstable how is the state's (biopolitical) power enacted or what weight ought to be given stereotypes when Zimbabwean-ness seems to exist on a sliding scale. Although these questions remain unanswered at the moment, perhaps these stories invite further investigation.

I end with a final anecdote. One morning I sat with a group of Zimbabweans on the street next to a house fronted by a large concrete security wall. As we sat, one of the residents of the household yelled over the fence for us to relocate across the street, rather than remain in front of his yard. Both sides begin to jaw back and forth, as other members of the household come out to see what is happening. At one point, one of the Zimbabwean men in the group shouts, "We are standing on the street! You are not the city council!" The encounter lasts for about 20 minutes as both sides periodically hurl insults at one another. The tension of the moment is finally broken when the same man threatens to use muti to turn the homeowners into hares. Hearing this, a passing Motswana man calls out in response, “Don't be scared. If they can use muti why haven’t they used it on Mugabe?" This causes everyone to laugh and the group relents, moving across the street. Observing the half-serious argument, I got the sense that it unfolded merely as a way to pass some time and break up the monotony of the day. At the same time, both the Zimbabweans and Batswana knew that the threats to call the police were idle ones; nobody actually believed that the police would come. "Why would any come? We will just run. Who can catch us? It is a waste of time for them." Another chimed in, adding that since it was payday we shouldn't expect see many patrols throughout the day. "Their minds aren't on their jobs. It is on their money." The remainder of that Friday morning in White City continued without incident, and without any police sightings either.

\footnotetext{
${ }^{64}$ Fontein, 'Anticipating the Tsunami', p. 390.

${ }^{65}$ A. L. Tsing, 'From the Margins', Cultural Anthropology, 9,3 (1994), 279-280.
} 


\section{References}

\section{Primary Sources}

Botswana National Archives, BNB 5316, Charles Edward Fuller, A Study of the Squatter Population in Gaberones: Undertaken for the Town Council of Gaberones July-August 1967.

Botswana National Archives, Department of Public Works BNB 1098, Gaberones Capital Project: Draft Town Plan Report, 1962.

Botswana National Archives, Ministry of Local Government and Land Audit Department 1 Box 27, Commissioner of Police, Savingram to the P. S. Ministry of Home Affairs, 26 August 1965.

Botswana National Archives, Ministry of Local Government and Land Audit Department 1 Box 27, Commissioner of the Police, Savingram to the P. S. Ministry of Home Affairs, Chief Immigration Officer, P. S. of Local Government, P. S. Ministry of Labour and Social Services, 1 November 1965.

Botswana National Archives, Ministry of Local Government and Land Audit Department 1 Box 27, Squatters: Gaborone Town Council 10 August 1966 - 2 May 1968, Q. K. J. Masire memo on Security - Disturbances Gaberones Township, 9 Nov. 1965.

Botswana National Archives, Ministry of Local Government and Lands Division C. HA. 21/19 Volume 1, Squatter Problem: Naledi, 1967-1968, Commissioner of Police, Savingram to P. S. Ministry of Home Affairs, P. S. Ministry of Labour and Social Services, P. S. Ministry of Local Government, Immigration Control Officer, 6 December 1966.

Botswana National Archives, Ministry of Local Government and Lands Division C. HA. 21/19 Volume 1, Squatter Problem: Naledi 1967-1968, Permanent Secretary, Savingram to District Commissioners of Mochudi, Molepolole, and Gaberones, 13 January 1967. 
Secondary Sources

Acemoglu, D., Johnson S., and Robinson, J. A., 'An African Success Story: Botswana' (CEPR

Discussion Papers 3219, Centre for Economic Policy Research, London, 2002).

Agamben, G., Homo Sacer: Sovereign Power and Bare Life (Stanford: Stanford University Press, 1998).

Bauman, Z., Wasted Lives: Modernity and its Outcasts (Cambridge: Polity Press, 2004).

Bigo, D., 'Security and Immigration: Toward a Critique of the Governmentality of Unease', Alternatives, 27 (2002).

Bratton, M. and Masunungure, E., 'Popular Reactions to State Repression: Operation Murambatsvina in Zimbabwe', African Affairs, 106, 422 (2007).

Brown, W., Walled States, Waning Sovereignty (New York: Zone Books, 2010).

Campbell, E. K., 'Attitudes of Batswana Citizens Towards Immigrants: Signs of Xenophobia?', International Migration, 41, 4 (2003).

Campbell, E. K., 'Reflections on Illegal Immigration in Botswana and South Africa', African Population Studies, 21, 2 (2006).

Comaroff, J. and Comaroff, J., 'Naturing the Nation: Aliens, Apocalypse and the Postcolonial State', Journal of Southern African Studies, 27, 3 (2001).

Comaroff, J. and Comaroff, J., 'Reflections on Liberalism, Policulturism, and ID-ology: Citizenship and Difference in South Africa', Social Identities, 9, 4 (2003).

Comaroff, J. and Comaroff, J., 'Figuring Crime: Quantifacts and the Production of the Unreal', Public Culture, 18, 1 (2006).

Cueppens, B. and Geschiere, P., 'Autochthony: Local or Global? New Modes in the Struggle Over Citizenship and Belonging in Africa and Europe', Annual Review of Anthropology (2005).

de Certeau, M and Rendall, S. (translator), The Practice of Everyday Life (Los Angeles: University of California Press, 1984).

Dodson, B., 'Locating Xenophobia: Debate, Discourse and Everyday Experience in Cape Town, South Africa', Africa Today, 56, 3 (2010).

Fontein, J., 'Anticipating the Tsunami: Rumours, Planning and the Arbitrary State in Zimbabwe', Africa: The Journal of the International Africa Institute, 79, 3 (2009).

Foucault, M., Society Must Be Defended (London: Allen Lane, 2003).

Gabotlale, B., 'Bus Rank Business Counts Losses After 'War', Mmegi, 6 May 2004.

Geschiere, P., The Perils of Belonging: Autochthony, Citizenship, and Exclusion in Africa and Europe (Chicago: University of Chicago Press, 2009).

Geschiere, P. and Jackson, S. (eds), 'Autochthony and the Crisis of Citizenship', African Studies Review (Special Issue), 49, 2 (2006).

Geschiere, P. and Nyamnjoh, F., 'Capitalism and Autochthony: The Seesaw of Mobility and Belonging', Public Culture, 12, 2 (2000).

Good, K., 'At the Ends of the Ladder: Radical Inequalities in Botswana', The Journal of Modern African Studies, 31, 2 (June 1993).

Good, K., 'The State and Extreme Poverty: the San and Destitutes', The Journal of Modern African Studies, 37, 2 (June 1999).

Henk, D., 'The Botswana Defence Force: Evolution of a Professional African Military', African Security Review, 13, 4 (2004).

Landau, L. B., 'Transplants and Transients: Idioms of Belonging and Dislocation in Inner-City Johannesburg', African Studies Review, 49, 2 (September 2006).

Landau, L. B., 'Loving the Alien? Citizenship, Law and the Future in South Africa's Demonic Society', African Affairs, 109, 435 (2010).

Landau, L. B. and Monson, T., 'Displacement, Estrangement and Sovereignty: Reconfiguring State Power in Urban South Africa', Government and Opposition, 43, 2 (2008). 
Leith, J. C., 'Why Botswana prospered' (Canadian Economics Association Thirty-Fourth Annual Meetings, University of British Columbia, June 2000).

Low, S., On the Plaza: The Politics of Public Space and Culture (Austin: University of Texas Press, 2000).

Maharaj, B., 'Migrants and Urban Rights: Politics of Xenophobia in South African Cities', L'Espace Politique, 8, 2 (2009).

Marinaro, I. C., 'Between Surveillance and Exile: Biopolitics and the Roma in Italy', Bulletin of Italian Politics, 1, 2 (2009).

Marr, S., 'Spaces of Aspiration, Liberation and Exclusion: The Politics of Urban Space in an African Democracy' (PhD thesis, University of Florida, 2008).

Marr, S., "If You are With Ten, Only Two Will be Batswana": Nation-Making and the Public Discourse of Paranoia in Botswana', Canadian Journal of African Studies (forthcoming in 2012).

Maundeni, Z., 'The Politics of Poverty in Botswana', Botswana Notes and Records, 23 (2003).

McGregor, J., 'Abject Spaces, Transnational Calculations: Zimbabweans in Britain Navigating Work, Class and the Law', Transactions of the Institute of British Geographers, 33, 4 (2008).

Mmegi, 'This Xenophobic Behavior Must Stop', 5 May 2004 $<$ http://www.mmegi.bw/2004/May/Wednesday5/10680060701279.html > (24 January 2006).

Mmegi, 'The Neighbourly-Burden that is Zimbabwe', 26 October 2006 <http://www.mmegi.bw/2006/October/Thursday26/9976358061774.html> (26 October 2006).

Morapedi, W., 'Post-Liberation Xenophobia in Southern Africa: The Case of the Influx of Undocumented Zimbabwean Immigrants in Botswana, c. 1995-2004', Journal of Contemporary African Studies, 25, 2 (2007).

Murray, M. J., 'Alien Strangers in Our Midst: The Dreaded Foreign Invasion and 'Fortress South Africa', Canadian Journal of African Studies, 37, 2/3 (2003).

Musoni, F., 'Operation Murambatsvina and the Politics of Street Vendors in Zimbabwe', Journal of Southern African Studies, 36, 2 (June 2010).

Neocosmos, M., 'The Politics of Fear and the Fear of Politics: Reflections on Xenophobic Violence in South Africa', Journal of Asian and African Studies, 43, 6 (2008).

Nyamnjoh, F. B., 'Local Attitudes towards Citizenship and Foreigners in Botswana: An Appraisal of Recent Press Stories', Journal of Southern African Studies, 28, 4 (2002).

Nyamnjoh, F. B., Insiders and Outsiders: Citizenship and Xenophobia in Contemporary Southern Africa (Dakar: CODESRIA, 2006).

Pasura, D., 'A Fractured Transnational Diaspora: The Case of Zimbabweans in Britain', International Migration, (2011).

Pegg, S., 'Presidential Succession and Academic Freedom: Botswana Deports Leading Political Scientist Kenneth Good', PS Online, (October 2005).

Picard, L. A. (ed), The Evolution of Modern Botswana (Lincoln: University of Nebraska Press, 1985).

Potts, D., 'Restoring Order'? Operation Murambatsvina and the Urban Crisis in Zimbabwe', Journal of Southern African Studies, 32, 4 (June 2006).

Rajaram, P. K. and Grundy-Warr, C., 'The Irregular Migrant as Homo Sacer: Migration and Detention in Australia, Malaysia, and Thailand', International Migration, 42, 1 (2004).

Reid, J., 'Life Struggles: War, Discipline, and Biopolitics in the Thought of Michel Foucault', Social Text, 24, 1 (2006).

Saleshando, D., 'What is the Worth of Our Independence?', Mmegi, 8 May 2006 <http://www.mmegi.bw/2006/May/Monday8/274371337117.html> (8 May 2006).

Samatar, A. I., An African Miracle: State and Class Leadership and Colonial Legacies in Botswana Development (Portsmouth: Heinemann, 1999).

Schinkel, W., 'From Zoepolitics to Biopolitics: Citizenship and the Construction of 'Society', European Journal of Social Theory, 13, 2 (2010).

Scott, J. C., Seeing Like a State: How Certain Schemes to Improve the Human Condition Have Failed (New Haven: Yale University Press, 1998). 
Stedman, S. J. (ed), Botswana: The Political Economy of Democratic Development (Boulder: Lynne Rienner Publishers, 1993).

Sunday Standard, 'Botswana, South Africa Deport 140,000 Zimbabweans in 2006, Police', 29 January $2007<$ http://sundaystandard.info/print.php?NewsID=929> (29 January 2007).

Taylor, I., 'The Limits of the 'African Miracle': Academic Freedom in Botswana and the Deportation of Kenneth Good', Journal of Contemporary African Studies, 24, 1 (January 2006).

Tsing, A. L., 'From the Margins', Cultural Anthropology, 9, 3 (1994).

Werbner, R. (ed), 'Minorities and Citizenship in Botswana', Journal of Southern African Studies (Special Issue), 28, 4 (2002).

Werbner, R., Reasonable Radicals and Citizenship in Botswana: The Public Anthropology of Kalanga Elites (Bloomington: Indiana University Press, 2004).

White, L., Speaking with Vampires: Rumor and history in colonial Africa (Berkeley: University of California Press, 2000). 